\title{
Coins of the First Century Roman Governors of Judaea AND THEIR MOTIFS
}

\author{
David M. Jacobson \\ Department of Classics, King's College London
}

\begin{abstract}
This article examines the motifs on the coins struck in Judaea under the auspices of local Roman governors (prefects and procurators) between the dismissal of the ethnarch, Herod Archelaus, in $6 \mathrm{CE}$ and the eve of the First Jewish Revolt which broke out in $66 \mathrm{CE}$. Although the governors were only designated by the title procurator from the mid-first century onwards, this series of coins is conventionally referred to as "procuratorial." All are bronzes minted in Jerusalem in a single denomination, generally identified as the prutah, and bear aniconic motifs. Because they carry year dates, we know that these coins were issued fairly sporadically and the possible reasons for this are reviewed. The coin types are analysed and their respective origins and meanings identified. An attempt is made to assess the extent to which their motifs support the picture presented in the literary sources of the changing political climate in both in Judaea and Rome over the period in which these coins were minted.
\end{abstract}

Keywords: Judaean coins, procuratorial coinage, Roman provincial coinage, coin motifs, coin types, Roman prefects of Judaea, Roman procurators of Judaea, Roman Palestine, Second Temple period, Pontius Pilate.

\section{Introduction}

Following Augustus' dismissal of Herod Archelaus, who succeeded his father Herod the Great as ruler of Judaea, after charges were levelled against him by the Jews and Samaritans of cruelty and tyranny, Judaea was placed under direct Roman rule. Thereby Judaea was "delivered from kingship and such forms of rule, [to] be joined to (the province of) Syria, and be made subject to the governors sent there."' This statement is important, because it reminds us that the governors of Judaea were subordinate to the legates of Syria, so that when the governors were faced with challenges that they could not deal with on their own, the Syrian legate would step in. 
There were to be two periods of direct Roman rule, from 6-41 CE and from 44-66 $\mathrm{CE}$, punctuated by a short interregnum of home-rule under Agrippa I. Altogether, the names of 14 governors are recorded. There is a degree of uncertainty about two of the names and for some the exact periods of their appointment, ${ }^{2}$ indicated in Table 1, which is compiled from Schürer (1973) and Kokkinos (2012); the names and dates of the Roman governors cited in Schürer represent the broad consensus. Those to whom the issue of coins can be attributed, namely six out of the 14 governors, are indicated by an asterisk (*). All references to the governors in ancient textual sources and known inscriptions are conveniently listed by Kokkinos. ${ }^{3}$

Table 1. List of Roman governors of Judaea from 6 to $66 \mathrm{CE}$

\begin{tabular}{|l|c|c|c|}
\hline \multicolumn{2}{|c|}{ Schürer 1973, 382-383, 455-470 } & \multicolumn{2}{c|}{ Kokkinos 2012, 104-106 } \\
\hline Governor & $\begin{array}{c}\text { Period of tenure, } \\
\text { CE }\end{array}$ & Governor & Period of tenure, CE \\
\hline Coponius* & $6-9$ & Coponius* & $6 / 7-8 / 9$ \\
\hline Marcus Ambibulus* & $9-12$ & Marcus Ambivius* & $9 / 10-11 / 12$ \\
\hline Annius Rufus & $12-15$ & Annius Rufus & $12 / 13-14 / 15$ \\
\hline Valerius Gratus* & $15-26$ & Valerius Gratus* & $15 / 16-25 / 26$ \\
\hline Pontius Pilatus* & $26-36$ & Pontius Pilatus* & $26 / 27-35 / 36$ \\
\hline Marcellus & 36 or 37 & Marcellus & $36 / 37$ \\
\hline Marullus & $37-41$ & Marullus & $37 / 38-40 / 41$ \\
\hline Cuspius Fadus & $44-? 46$ & Cuspius Fadus & $44 / 45-45 / 46$ \\
\hline Tiberius Iulius Alexander & $? 46-48$ & Tiberius Iulius Alexander & $46 / 47-47 / 48$ \\
\hline Ventidius Cumanus & $48-$ c. 52 & Ventidius Cumanus & $48 / 49-51 / 52$ \\
\hline Antonius Felix* & c. 52-60 & Tiberius Claudius Felix* & $52 / 53-56 / 57$ \\
\hline Porcius Festus* & $60-62$ & Porcius Festus* & $57 / 58-58 / 59$ \\
\hline Albinus & $62-64$ & [Lucceius?] Albinus & $59 / 60-62 / 63$ \\
\hline Gessius Florus & $64-66$ & Gessius Florus & $63 / 64-64 / 65$ \\
\hline
\end{tabular}

The administration of the country was henceforth headed by a governor of equestrian rank appointed by the emperor, who wielded wide-ranging powers with full military command and judicial authority in Judaea, including exercising of capital punishment, starting with the appointment of Coponius. ${ }^{4}$ The usual title for a governor of equestrian rank was praefectus (eparchos in Greek), confirmed in this case by the use of this title for

2 The disputed names are those of Marcus Ambibulus/Ambivius and Antonius/Claudius Felix, see Kokkinos 1990; Kokkinos 2012, 106-107.

3 Kokkinos 2012, 104-106.

4 Jos. BJ 2.117; AJ 18.2. 
Pontius Pilate (Pilatus) on a monumental lapidary inscription. ${ }^{5}$ From the reign of Claudius, the title procurator (epitropos) came to be applied to the governor of Judaea and for other provinces of the same type, stressing the financial responsibilities of the post. ${ }^{6}$ The normal seat of the Roman governors of Judaea was Caesarea Maritima, although they frequently visited Jerusalem, staying in the palace established by Herod adjacent to the west wall of the city. ${ }^{7}$

While Judaea had rendered tribute to Rome since 63 BCE, when it had come under Roman suzerainty, after it became a Roman province, its population was obliged to pay additional taxes to those that were levied by the Herodian rulers, including in particular a head tax (tributum capitis) following a census conducted of the entire population and each person's assets, which was carried out by Quirinus, the legate of Syria, following the removal of Archelaus. ${ }^{8}$

\section{Overview of the Coins of the Roman Governors}

All the coins issued in Judaea under the authority of the governors are of a single bronze denomination, generally referred to as a prutah, 15 to $17 \mathrm{~mm}$ in diameter and mostly weighing in the range 1.5 to $2.5 \mathrm{~g}$. Most of D. T. Ariel's arguments in support of Jerusalem as the place of the mint of these coins are persuasive: (1) the existence of a longstanding mint in Jerusalem, (2) having a similar fabric, (3) being of a size and weight appropriate to the principal denomination (prutah) of previous coins minted in Jerusalem, (4) having aniconic motifs. ${ }^{9}$ Those coins issued for the first two governors of Judaea are dated to Augustus' Actian era (beginning 31/30 BCE). An alternative Augustan era of 27 $\mathrm{BCE}$ advanced by N. Kokkinos is based on a contested reading of the date inscribed on coin $R P C$ I, no. $4954=T J C$, no. 312; Fig. 1.10 .

5 Boffo 1994, 217-221, no. 25. In the Latin text of Tacitus (Ann. 15.44), Pilate's title is (wrongly) given as procurator and Philo (Leg. 299) refers to him as an epitropos in Greek. Josephus uses the same term to designate Roman governors of Judaea (Schürer 1973, 359 and note 26).

6 Schürer 1973, 358-359. In the Greek NT the term used for the Roman governors is hègemōn (= "leader").

7 Schürer 1973, 361 and notes 37-38.

8 Jos. AJ 17.355-18.1-3; cf. Luke 2.1-2.

9 Ariel 1982, 288-289. Ariel has obtained archaeological proof for the minting coins of the Roman governors in Jerusalem (Ariel 2011). The method employed in their production was the same as that used from the last third of the second century BCE to 70 CE (Ariel 2012, 51-75; TJC, 176). Production entailed first preparing flans by casting the copper alloy into split moulds of matrix design and afterwards striking the heated flans with appropriate dies for the coin issue. The half moulds contained parallel strips of connected circular cavities, connected by short, narrow runners. Examples of such flan moulds dated to the Second Temple period have been found at various locations in Jerusalem. Coins were struck hot, either while the flans were still connected or after they had been prised apart (Zlotnik 2012).

10 Kokkinos 2012, 92-93; cf. Ariel 2014, 387-388. A lynchpin of Kokkinos' proposal for an era of 27 BCE relies on a reading of the date letters on some of these coins as (year 33). Although the date letter in question does seem to resemble the Greek $\Gamma(=3)$, in Y. Meshorer's opinion $(T J C, 168,256)$, it was intended to be read as $\varsigma(=6)$, making the year 36. Moreover, of the numerous coins of this type found in controlled excavations, recorded in the Israel Antiquities Authority database, none reads $\mathrm{L} \Lambda \Gamma$ but " 55 are dated to the equivalent of $\Lambda \varsigma^{\prime \prime}$ (Ariel 2014, 388). 
On the "procuratorial coins," the minting authority is given as the serving emperor, either by name (Tiberius, Claudius, or Nero) or simply as "Caesar"; ${ }^{11}$ none of the governors is named. Two coins mention IOY $\Lambda$ IA, Julia Augusta, the second spouse of Augustus (as Livia was known after her adoption into the Julian family), ${ }^{12}$ and one of the coins mentions Julia Agrippina, better known as Agrippina the Younger, a great-granddaughter of Augustus, a sister of Caligula, the wife of Claudius and mother of Nero. ${ }^{13}$ Also named are (Tiberius Claudius) Caesar Britannicus, the son of Claudius and his third wife Valeria Messallina. After the reign of Augustus, the coins are dated to the regnal years of his successors. This corpus of coins is listed in Table 2 and the years in which the coins were issued are summarised in Table 3.

The various motifs that appear on the coins of Judaea struck for the Roman governors are compiled in Table 4. Imperial names, titles and occasional regnal years are inscribed in a wreath, a format that was universally employed on Hellenistic and Roman coins, and also those of the Hasmonaean and Herodian rulers.

Table 2. The coins of the first century CE Roman provincial coins of Judaea, subsequent to the deposition of Herod Archelaus, and up to the eve of the Jewish War

\begin{tabular}{|c|c|c|c|}
\hline Issuing authority & Obverse & Reverse & Cat. nos. \\
\hline \multicolumn{4}{|l|}{ Augustus } \\
\hline $\begin{array}{l}\text { Marcus Ambibulus } \\
\text { (or Ambivius) }\end{array}$ & $\begin{array}{l}\text { Ear of barley } \\
\text { or wheat; } \\
\text { KAICAPOC }\end{array}$ & $\begin{array}{l}\text { Palm tree; } \\
\mathrm{L} \Lambda \varsigma(\text { Year } 36=5 / 6 \mathrm{CE}) \\
\text { Ditto; L } \Lambda \Theta(\text { Year } 39=8 / 9 \\
\text { CE) } \\
\text { Ditto; } \mathrm{L}[\Lambda] \mathrm{M}(\text { Year } 40= \\
\text { 9/10 CE }) \\
\text { Ditto; }[\Lambda] \mathrm{MA}(\text { Year } 41= \\
\text { 10/11 CE) }\end{array}$ & $\begin{array}{l}R P C \text { I, no. } 4954=T J C, \text { nos. } \\
311-312 ; \text { Fig. } 1 . \\
R P C \text { I, no. } 4955=T J C, \text { no. } \\
313 \\
\text { RPC I, no. } 4956=T J C, \text { no. } \\
314 \\
\text { RPC I, no. } 4957=T J C, \text { no. } \\
\text { 315; Fig. } 2\end{array}$ \\
\hline \multicolumn{4}{|l|}{ Tiberius } \\
\hline \multirow[t]{3}{*}{ Valerius Gratus } & $\begin{array}{l}\text { KAICAP in } \\
\text { wreath }\end{array}$ & $\begin{array}{l}\text { Conjoined, facing cornu- } \\
\text { copias with fillets; TIB L B } \\
\text { (Year } 2=15 / 16 \mathrm{CE} \text { ) }\end{array}$ & $\begin{array}{l}R P C \text { I, no. } 4958=T J C \text { no. } \\
\text { 316; Fig. } 3\end{array}$ \\
\hline & $\begin{array}{l}\text { IOYAIA in } \\
\text { wreath }\end{array}$ & Ditto & TJC, no. 318 \\
\hline & $\begin{array}{l}\text { IOYAIA in } \\
\text { wreath }\end{array}$ & $\begin{array}{l}\text { Laurel branch; } \\
\text { L B (Year } 2=15 / 16 \mathrm{CE})\end{array}$ & $\begin{array}{l}R P C \text { I, no. } 4959=T J C \text {, no. } \\
\text { 317; Fig. } 4\end{array}$ \\
\hline
\end{tabular}

11 No coins were issued by the Roman governors of Judaea during the unsettled reign of Caligula.

$12 R P C$ I, no. $4964=T J C$, no. 327 and $R P C$ I, no. $4967=T J C$, no. 331 . On the accompanying legend, IOY AIA KAICAPOC, literally "Julia, of Caesar," see Taylor 2006, 560. This ungrammatical wording might simply have arisen from the substitution of IOY $\Lambda I A$, in the nominative form, for the genitive TIBEPIOY from the legend on the obverse.

$13 R P C$ I, no. $4970=T J C$, no. 342. 


\begin{tabular}{|c|c|c|c|}
\hline \multirow[t]{7}{*}{ Issuing authority } & Obverse & Reverse & Cat. nos. \\
\hline & $\begin{array}{l}\text { KAICAP in } \\
\text { wreath }\end{array}$ & Ditto & TJC 319 \\
\hline & $\begin{array}{l}\text { KAICAP in } \\
\text { wreath }\end{array}$ & $\begin{array}{l}\text { Caduceus between crossed } \\
\text { cornucopias; TIBEPIOY L } \Gamma \\
\text { (Year } 3=16 / 17 \text { CE) }\end{array}$ & $\begin{array}{l}R P C \text { I, no. } 4960=T J C, \text { no. } \\
\text { 320; Fig. } 5\end{array}$ \\
\hline & $\begin{array}{l}\text { IOY } \Lambda I A \text { in } \\
\text { wreath }\end{array}$ & $\begin{array}{l}\text { Three lilies L } \Gamma(\text { Year } 3= \\
16 / 17 \mathrm{CE})\end{array}$ & $\begin{array}{l}R P C \text { I, no. } 4961=T J C \text {, no. } \\
\text { 321; Fig. } 6\end{array}$ \\
\hline & $\begin{array}{l}\text { Kantharos; } \\
\text { KAICAP } \\
\text { L } \Delta(\text { Year } 4= \\
17 / 18 \mathrm{CE})\end{array}$ & $\begin{array}{l}\text { Vine branch, tendril and leaf; } \\
\text { TIBEPIOY }\end{array}$ & $\begin{array}{l}R P C \text { I, no. } 4962=\mathrm{TJC} \text {, no. } \\
\text { 325; Fig. } 7\end{array}$ \\
\hline & $\begin{array}{l}\text { Amphora; L } \Delta \\
\text { (Year } 4=17 / 8 \\
\text { CE) }\end{array}$ & 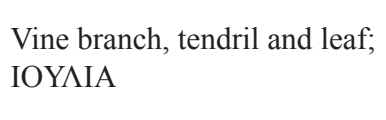 & $\begin{array}{l}R P C \text { I, no. } 4963=T J C \text {, no. } \\
\text { 326; Fig. } 8\end{array}$ \\
\hline & $\begin{array}{l}\text { TIB KAICAP } \\
\text { in wreath }\end{array}$ & $\begin{array}{l}\text { Palm branch; IOY IIA } \\
\text { L } \Delta \text { (Year } 4=17 / 18 \text { CE) } \\
\text { Ditto; L E (Year } 5=18 / 19 \\
\text { CE) } \\
\text { Ditto; L AI (Year } 11=24 / 25 \\
\text { CE) }\end{array}$ & $\begin{array}{l}R P C \mathrm{I}, \text { no. } 4964=T J C, \text { no. } \\
327 \\
R P C \text { I, no. } 4965=T J C \text {, no. } \\
328 \text {; Fig. } 9 \\
R P C \text { I, no. } 4966=T J C \text {, no. } \\
329\end{array}$ \\
\hline \multirow{2}{*}{ Pontius Pilatus } & $\begin{array}{l}\text { Simpulum; } \\
\text { TIBEPIOY } \\
\text { KAICAPOC L } \\
\text { I } \varsigma \text { (Year } 16= \\
29 / 30 \mathrm{CE})\end{array}$ & $\begin{array}{l}\text { Three ears of grain tied to } \\
\text { a frame or tripod: IOYAIA } \\
\text { KAICAPOC }\end{array}$ & $\begin{array}{l}R P C \text { I, no. } 4967=T J C \text {, no. } \\
\text { 331; Fig. } 10\end{array}$ \\
\hline & $\begin{array}{l}\text { Lituus; } \\
\text { TIBEPIOY } \\
\text { KAICAPOC }\end{array}$ & $\begin{array}{l}\text { L IZ }(\text { Year } 17=30 / 31 \mathrm{CE}) \text { in } \\
\text { wreath } \\
\text { L IH }(\text { Year } 18=31 / 32 \mathrm{CE}) \\
\text { in wreath }\end{array}$ & $\begin{array}{l}R P C \text { I, no. } 4968=T J C, \text { no. } \\
\text { 333; Fig. } 11 \\
R P C \text { I, no. } 4969=T J C, \text { no. } \\
334\end{array}$ \\
\hline \multicolumn{4}{|l|}{ Claudius } \\
\hline \multirow{2}{*}{$\begin{array}{l}\text { Antonius (or } \\
\text { Claudius) Felix }\end{array}$} & $\begin{array}{l}\text { IOY } \Lambda \text { IA } \\
\text { АГРІППINA } \\
\text { in wreath }\end{array}$ & $\begin{array}{l}\text { Crossed pair of palm branch- } \\
\text { es; TI K } \Lambda \text { AY } \triangle \text { IOC KAICAP } \\
\text { ГEPM; L I } \triangle \text { (Year } 14=54 \\
\text { CE) in field }\end{array}$ & $\begin{array}{l}R P C \text { I, no. } 4970=T J C \text {, no. } \\
342 ; \\
\text { Fig. } 12\end{array}$ \\
\hline & $\begin{array}{l}\text { Palm tree; } \\
\text { BPIT KAI; } \\
\text { L I } \Delta \text { (Year } 14 \\
=54 \text { CE) in } \\
\text { field }\end{array}$ & $\begin{array}{l}\text { Two crossed shields and } \\
\text { spears; NEPW K } \Lambda \text { AY } \\
\text { KAICAP }\end{array}$ & $\begin{array}{l}R P C \text { I, no. } 4971=T J C \text {, no. } \\
340 ; \\
\text { Fig. } 13\end{array}$ \\
\hline \multicolumn{4}{|l|}{ Nero } \\
\hline Porcius Festus & $\begin{array}{l}\text { NEPWNOC in } \\
\text { wreath }\end{array}$ & $\begin{array}{l}\text { Palm branch; L } \varsigma(\text { Year } 5= \\
\text { 58/59 CE) KAICAPOC }\end{array}$ & $\begin{array}{l}R P C \text { I, no. } 4972=T J C, \text { no. } \\
\text { 345; Fig. } 14\end{array}$ \\
\hline
\end{tabular}


Table 3. The year dates represented on the coins of the Roman governors of Judaea and their calendar equivalents

\begin{tabular}{|l|c|l|}
\hline \multicolumn{1}{|c|}{ Year Date on Coin(s) } & Calendar Date, CE & Emperor \\
\hline Actian year 36 & $5 / 6$ & Augustus \\
\hline Actian year 39 & $8 / 9$ & Augustus \\
\hline Actian year 40 & $9 / 10$ & Augustus \\
\hline Actian year 41 & $10 / 11$ & Augustus \\
\hline Regnal year 2 & $15 / 16$ & Tiberius \\
\hline Regnal year 3 & $16 / 17$ & Tiberius \\
\hline Regnal year 4 & $17 / 18$ & Tiberius \\
\hline Regnal year 5 & $18 / 19$ & Tiberius \\
\hline Regnal year 11 & $24 / 25$ & Tiberius \\
\hline Regnal year 16 & $29 / 30$ & Tiberius \\
\hline Regnal year 17 & $30 / 31$ & Tiberius \\
\hline Regnal year 18 & $31 / 32$ & Tiberius \\
\hline Regnal year 14 & 54 & Claudius \\
\hline Regnal year 5 & $58 / 59$ & Nero \\
\hline
\end{tabular}

Table 4. Motifs on the coins of the Judaea minted under the Roman governors in the first century CE

\begin{tabular}{|l|l|}
\hline \multicolumn{1}{|c|}{ Motif } & \multicolumn{1}{|c|}{ Precedents on coins } \\
\hline Ear of barley or wheat & $\begin{array}{l}\text { Prutah of Mattathiah Antigonus, shown between facing cornucopias } \\
\text { (TJC, nos. 40-40b). A grain of barley or wheat is a motif on a rare } \\
\text { prutah of Herod Antipas (1 BCE/1 CE; Hendin 2003-2006). It was } \\
\text { a symbol of fecundity. }\end{array}$ \\
\hline Palm tree & $\begin{array}{l}\text { As a single motif on a rare prutah of Herod Antipas (1 BCE/1 CE; } \\
\text { Hendin 2003-2006). It is a symbol of fecundity and of Judaea. }\end{array}$ \\
\hline $\begin{array}{l}\text { Conjoined, facing cornu- } \\
\text { copias with fillets }\end{array}$ & $\begin{array}{l}\text { Large bronze of Mattathias Antigonus (TJC, no. 36). Also occurs } \\
\text { together with a plant species (pomegranate/poppy, ear of barley/wheat) } \\
\text { between facing cornucopias on coins of several Hasmonaean kings. }\end{array}$ \\
\hline Caduceus between \\
crossed cornucopias & $\begin{array}{l}\text { Prutot of Herod the Great (RPC I, no. 4911 = TJC, no. 59) and Herod } \\
\text { Archelaus (RPC I, no. 4192 = TJC, no. 68); based on a Roman motif } \\
\text { first used as a coin type on a denarius of Antony in 40 BCE (RRC, no. } \\
520 / 1) . \text { It symbolises "peace and concord, made possible by benevo- } \\
\text { lent rule" (Jacobson 2012, 158). }\end{array}$ \\
\hline \multirow{2}{*}{ Three lilies } & $\begin{array}{l}\text { Single lilies of the same type appear on earlier Judaean coins going } \\
\text { back to the late Persian period (TJC, no.15) and the first issue of John } \\
\text { Hyrcanus I (in the name of Antiochus VII) (TJC, nos. 30-31; SC II, } \\
\text { no. 2123.2). It has special significance in Jewish tradition (Jacobson } \\
\text { 2013b, 16-17 and refs.). }\end{array}$ \\
\hline
\end{tabular}




\begin{tabular}{|c|c|}
\hline Motif & Precedents on coins \\
\hline Kantharos & Graeco-Roman drinking vessel; no antecedents on Judaean coins. \\
\hline Amphora & Graeco-Roman storage vessel; no antecedents on Judaean coins. \\
\hline Vine leaf and tendril & $\begin{array}{l}\text { A vine, grapes, tendril and leaf appear on a prutah of Herod Archelaus } \\
(R P C \mathrm{I}, 4917=T J C, \text { no. } 73) .\end{array}$ \\
\hline Palm branch & $\begin{array}{l}\text { A popular symbol, which represented victory in Greek iconography, } \\
\text { especially when shown filleted, and frequently employed on Hasmo- } \\
\text { naean and Herodian coins, beginning with John Hyrcanus I (Jacobson } \\
\text { 2013a, 49-52). }\end{array}$ \\
\hline Lituus & Roman sacerdotal object, a regular symbol of the augures. \\
\hline Simpulum & $\begin{array}{l}\text { Roman sacerdotal object, a regular symbol of the pontifices and often } \\
\text { shown with a lituus. }\end{array}$ \\
\hline Laurel & $\begin{array}{l}\text { The laurel, shown either as a single sprig, or as a wreath enclosing the } \\
\text { name/title of the emperor or empress, was an established emblem of } \\
\text { imperial authority. A laurel wreath had become the de rigueur head- } \\
\text { band on images of Roman emperors. }\end{array}$ \\
\hline Three ears of grain & $\begin{array}{l}\text { Livia was frequently identified with Demeter/Ceres in Roman ico- } \\
\text { nography, where she is commonly shown holding three ears of grain } \\
\text { (Strickert 2011, 172-173; Grether 1946, 222-252). }\end{array}$ \\
\hline $\begin{array}{l}\text { Two crossed shields and } \\
\text { spears }\end{array}$ & $\begin{array}{l}\text { A motif used by Claudius on a denarius and aureus struck in Lug- } \\
\text { dunum in } 41-45 \text { CE to celebrate his father's military successes in } \\
\left.\text { Germany (RIC I }{ }^{2} \text {, Claudius, nos. } 73-74\right) \text {. }\end{array}$ \\
\hline $\begin{array}{l}\text { Crossed pair of palm } \\
\text { branches }\end{array}$ & $\begin{array}{l}\text { A Herodian royal monogram used on coins of Herod the Great (Jacob- } \\
\text { son 2014). }\end{array}$ \\
\hline
\end{tabular}

\section{The First Period of Direct Roman Rule and Its Coins}

At the beginning of period of Roman rule, apart from the additional tax burden, the Jewish population seemed to have little to fear from direct Roman rule. It was freed from the clutches of an incompetent and authoritarian Herodian tetrarch and stood to benefit from better-regulated Roman administration. Initially that administration behaved, for the most part, with sensitivity towards the Jews, showing respect for their cult and customs. ${ }^{14}$ The Emperor Augustus and his consort, Livia, had set the example by presenting votive gifts to the Jerusalem Temple and sponsored sacrifices there. ${ }^{15}$ Concessions were made to Jewish religious ordinances. Thus, for example, Jews were exempt from military service to avoid conflict with their customs, including dietary laws, Sabbath observance and celebration of the festivals. ${ }^{16}$ They were exempted from emperor-worship

14 Schürer 1973, 379-381.

15 Schürer 1973, 379, note 117.

16 Schürer 1973,363 , note 45. 
(apart from a short transgression by the deranged Caligula) and excused from appearing before magistrates on the Sabbath and other Jewish holidays. Their strongly-held fetish against the display of human images was generally respected. Roman military detachments desisted from bringing their standards which bore the emperor's image with them to Jerusalem and the Roman administration took care to scrupulously avoid human or animal images on coins produced for use in Judaea.

For the two initial decades of this period, Judaea was relatively tranquil. The frequent issuing of coins during those years, bearing uncontroversial motifs, such as the conjoined cornucopias, lilies and regional agricultural produce, represented by an ear of grain, a vine leaf and palm tree laden with dates (Figs. 1, 2, 3, 6, 7 and 8; Tables 2 and 4) provides evidence that the early governors engaged in a sympathetic manner with their Jewish subjects and were responsive to their sensitivities. In fact, the pairing of a vine branch with leaf and tendril on coins with two-handled receptacles for wine (here a kantharos and an amphora; Figs. 7 and 8) issued during the governorship of Valerius Gratus seems to presage the motifs on the prutah coins of the produced by the Jewish insurgents during their War with Rome; compare Figs. 7 and 7a. ${ }^{17}$ Their fairly close similarity attests to the motifs on these issues of Gratus being congenial to Jewish traditions.

It is noteworthy that the majority of coin issues put into circulation by the Roman governors date from that early period. The sprig of laurel (Fig. 4) refers to Imperial authority, bearing in mind that it was the custom for Roman emperors to wear laurels. On the coins, a laurel wreath encircles the imperial name or title, representing the ultimate authority of the coins. In a similar vein, the conjoined cornucopias and crossed cornucopias flanking a caduceus (Fig. 5) can be interpreted as the Roman administration in Judaea being presented as the legitimate successor to those of the Hasmonaeans and Herodians, respectively.

The two prefects appointed under Tiberius (emperor from 14-37 CE), Valerius Gratus and Pontius Pilate, enjoyed the longest postings in Judaea of all ${ }^{18}$. During Gratus' administration there were more coin issues than for any other Roman governor. The emperor Tiberius had a reputation for leaving imperial appointees in their assigned posts for a long duration. ${ }^{19}$ Tacitus notes that under Tiberius, all was quiet, ${ }^{20}$ although it is possible to interpret the appearance of a palm branch, a martial symbol, on coins of Valerius Gratus from 17/18 CE onwards (Fig. 9) as alluding to the onset of

17 The coin of type of Gratus featuring the kantharos ( $R P C$ I, no. $4962=T J C$, no. 325) is strikingly similar to the cup shown on the bronze coins struck by the Jewish rebels in "year 2" of the War with Rome, contra Meshorer (AJC II, 112), who claimed that the vessels in the two cases are very different. Both vessels have a broad brim and a bulbous belly and they are raised on a stem with a knop from a conical base. The year date is marked on the same side of the coin in the two cases. Only the pairs of handles are of different shape. A lid is shown on the vessel on the Gratus coin as it is on the War coins of year 3. A kantharos is a characteristic type of Greek cup that was used to contain wine for ritual use (Elderkin 1924, 2-6), so these motifs probably represent gold vessels for wine donated by Augustus and Livia to the Temple (Jos. BJ 5.562). The large vine leaf on the reverse of both coins hangs in a similar way from a horizontal stem. Indeed, the designs on both sides are so similar that it is possible that the Gratus coin served as a model for the bronze prutot of years 2 and 3 struck by the Jewish rebels.

18 Jos. AJ 18.177.

19 Tac. Ann. 1.80; 4.6.

20 Tac. Hist. 5.9. 
troubled times in Judaea. We are informed that Gratus appointed four high priests in rapid succession, ${ }^{21}$ which might be symptomatic of his susceptibility to bribery, with payment taken by the governor for the grant of the high priesthood. ${ }^{22}$ With the appointment of Pontius Pilate, there was, to be sure, a marked increase of internal strife. His tenure is described by a contemporary as marred by misconduct, being stained by "the briberies, the insults, the robberies, the outrages and wanton injuries, the executions without trial, constantly repeated, the ceaseless and supremely grievous cruelty."${ }^{.23} \mathrm{By}$ nature, he was vindictive and unyielding. The antagonism that he engendered is highlighted by the following incidents:

1. Bringing troops to Jerusalem carrying standards decorated with busts of the emperor in violation of the practice set by his predecessors, who didn't allow their soldiers to enter Jerusalem with standards bearing such effigies. ${ }^{24}$

2. An incident mentioned by Philo, in which Pilate set up gold-plated votive shields in Herod's former palace in Jerusalem; they were without images, but inscribed with dedications to the emperor. ${ }^{25} \mathrm{We}$ are told that his intention was to cause annoyance to the city's population and, in any event, this deed succeeded in provoking an angry response.

3. Sequestering funds from the Temple treasury to construct or renovate an aqueduct for Jerusalem and then ordering his troops to violently suppress protests that his actions engendered, resulting in many fatalities. ${ }^{26}$

The trial and crucifixion of Jesus, over which Pilate undoubtedly presided (crucifixion being a Roman form of execution), is set against a backdrop of turbulence. Barabbas, who was detained by Pilate at the same time as Jesus, but then released from Roman custody in response to public clamour, is described as a lesstēs ('bandit') in John 18.40, a term used by Josephus to denote a revolutionary.

At length, it was Pilate's dispatch of troops to counter a large procession of Samaritans that led to the recall and trial of this discredited governor. ${ }^{27}$ Following the removal of Pilate, the Roman legate of Syria, Vitellius, sought to make amends for the unsavoury conduct of Pilate by visiting Jerusalem at the Passover and by way of further conciliatory gestures, he remitted all taxes levied on the sale of agricultural produce and handed over custody of the high-priestly vestments, which had been kept under Roman guardianship in the Antonia fortress, into Jewish safekeeping. ${ }^{28}$

The coin types of Pilate may reflect his hostile attitude towards the Jews and Samaritans; see Figs. 10 and 11). By giving prominence to specifically Roman cult objects, the simpulum (a ritual ladle with a short handle) and lituus (an augurer's staff ending in a spi-

21 Jos. $A J 18.34-35$.

22 Hendin 2010, 315.

23 Philo Leg. 302.

24 Jos. BJ 2.169-174; AJ 18.55-59.

25 Philo Leg. 299-305; see Smallwood 1981, 165-66; Schürer 1973, 386.

26 Jos. $B J$ 2.175-77; $A J$ 18.60-62. According to a recent study of their remains by Amit and Gibson (2014), the two aqueducts constructed in antiquity to bring water to Jerusalem from springs to the south of the city, the so-called Lower and Upper Aqueducts, predated Pilate, the first probably constructed in the late Hasmonaean period and the second by Herod the Great.

27 Jos. $A J$ 18.85-89.

28 Jos. $A J$ 18.90-95. 
ral) it is possible that his intention was to deliver a snub to these two groups. ${ }^{29}$ The lituus and simpulum are usually shown together as Roman sacerdotal emblems, representing two of the four great religious colleges (collegia) associated with the Roman priesthood. Of these the two most prominent were those of the pontifices, headed by the pontifex maximus (represented by a simpulum), and of the augures (by a lituus). The other two religious colleges were those of the quindecimviri sacris faciendus (denoted by a tripod) and the septemviri epulones (by a patera). Naturally, it is the symbols of the two foremost collegia that feature more often on the coins of the Julio-Claudians: they are depicted together on coins of Julius Caesar, ${ }^{30}$ Augustus, ${ }^{31}$ Tiberius, ${ }^{32}$ Caligula, ${ }^{33}$ Nero as Caesar under Claudius, ${ }^{34}$ and Nero. ${ }^{35}$

It was normal practice for Roman emperors to hold the office of the Pontifex Maximus and preside over the other religious colleges. Frequently, coin portraits of emperors are accompanied by a lituus and less often by a simpulum. The head of Augustus accompanied by a lituus is a particularly prolific combination on Roman provincial coins, with no less than 41 separate instances listed in $R P C .^{36}$ There are examples for all the Julio-Claudian emperors, including Tiberius. Bronze coins issued under Nero at Antioch, include examples where the emperor's head shares the obverse with a lituus and others where Nero's head is accompanied by a simpulum. ${ }^{37}$ Clearly, in this context the cultic implements are closely associated with imperial authority, so their appearance on the coins of Pontius Pilate may have been regarded by the Roman authorities as suitable inanimate substitutes for the emperor's portrait (here, Tiberius). Indeed, the legends alongside these motifs is appropriately TIBEPIOY KAICAPOC. There is a precedence for this display on coins of Herod the Great, where, as it is argued, the tripod, a principal emblem of Apollo, the patron deity of Augustus, stood in for a portrait of that emperor. ${ }^{38}$ All the same, there can be no doubt that the display of pagan cultic implements on Pilate's coins would have offended Jewish sensibilities.

29 Taylor 2006, 558-559; Hendin 2010, 317-318. The lituus was originally an Italic form of royal sceptre (Serv. Aen. 7.187), which later became an emblem of the emperor. It was also a cultic instrument of the augurs (augures), which they used to mark out portions of the sky where they would look for auspicious signs (Livy 1.18.6-9); see A. V. Siebert, 'Lituus' in bNP online, http://dx.doi.org/10.1163/1574-9347_bnp_e707900. The simpulum was a ritual ladle used by Roman priests (pontifices) to pour the wine needed for a sacrifice; see R. Hurschmann, 'Simpuvium' in bNP online, http://dx.doi.org/10.1163/1574-9347_bnp_e1113740. Both online entries were consulted on 12 August 2018.

$30 R R C$, nos. $467 / 1,480 / 3$.

31 RIC I², Augustus, nos. 205-212, 402 [Rome]; RPC I, nos. 314 [Caesaraugusta], 772b [Hadrumetum].

32 RPC I, nos. 713 [Hippo Regius], 946 [Cyrenaica].

$33 R P C I$, no. 3624 [Caesarea, Cappadocia].

34 RIC I², Claudius nos. 76-77, 107; RPC I, no. 4171 [Antioch].

$35 R P C$ I, nos. 4171, 4178 [Antioch]. The lituus and simpulum also appear together as reverse types on quadrantes struck in Rome under Augustus (RIC I², Augustus, nos. 421 and 424).

36 RPC I, 'Index 6.2: Reverse Types', 794-808. V. Gyori has noted obverse portraits of Augustus accompanied by a lituus on provincial coins of no less than 23 cities in North Africa and Asia; see Györi 2015, 47 and notes $11-12$.

37 Nero's head with (1) a lituus: RPC I, nos. 4172, 4303-4304, 4307-4308; (2) a simpulum: RPC I, nos. $4311-4312$.

38 Jacobson 2015, 95-96. 
Another motif on one of Pilate's comprises three ears of wheat or barley tied to a tripod (Fig. 10, reverse). The ears of corn constituted a well-established emblem of Ceres, the Roman goddess of agriculture and fecundity. Here, the specific reference is to the Empress Livia who was widely identified with Ceres. ${ }^{39}$ The drooping ears of grain may represent the departed Augustus and Livia and the single erect ear, Tiberius. ${ }^{40}$ This being the case, it is the only known contemporaneous coin that commemorates her death in January $29 \mathrm{CE}$ at the age of $86 .{ }^{41}$ Coins honouring Livia were issued in 30/31 and 33/34 CE by Philip the Tetrarch at Caesarea Paneas also commemorate Livia, and possibly her decease. ${ }^{42}$ They depict the draped bust of Livia, with the legend IOYAIA CEBACTH ("Empress Julia") on their obverse. The motif on their reverse comprises a hand grasping three ears of grain, with the legend КАРПОФОРО $(\mathrm{C})$ ("fruit-bearing"), a regular epithet applied to Demeter/Ceres in Hellenic tradition. ${ }^{43}$ The thread linking the three ears of grain, Ceres and Livia, therefore, is quite explicit.

The careful building of bridges by the Roman legate, Vitellius to the population of Judaea was largely undone by the impetuous Caligula, who attempted to have the imperial cult installed in the Jerusalem Temple. Fortunately, his nefarious plan was frustrated by the procrastinating tactics of Vitellius' successor, Petronius, and the timely death of the deranged emperor. ${ }^{44}$ No coins were issued by the prefect Marullus covering that tense period, nor by Marcellus who briefly preceded him.

During the brief interlude of semi-independent rule of Judaea by Agrippa I from 41 to $44 \mathrm{CE}$, there was only a single coin issue by that monarch in Jerusalem, also a prutah denomination. Dated to the 6 th year of his reign $(41 / 42 \mathrm{CE})$, it features a parasol on the obverse three ears of grain on the reverse. ${ }^{45}$ Alongside the parasol, an ancient symbol of royalty in the Middle East, is the inscription BАCIAEWC АГРІПА ("of King Agrip[p] a"), indicating that the emblem refers to his authority. ${ }^{46}$ The ears of grain here are likely

39 Strickert 2011, 170, 241-249; Taylor 2006, 560-561. Livia's association with Ceres is attested in sculpture, for example in a monumental statue of Julia Augusta (Livia) in the Louvre where the empress is represented with ears of grain in her left hand and a cornucopia in her left (Louvre inv. Ma 1242); see Bartman 1999, 45, fig. 42, 93-94, 106-110; Spaeth 1994, 88; Grether 1946, 243-244. Livia was also represented in the guise of Ceres throughout the Roman Empire on coins: e.g. RPC I, nos. 642-643 [Panormus]; nos. 763,769 [Paterna]; nos. 795-796 [Thapsus]; no. 1150 [Corinth]; no. 2368 [Pergamum]; no. 2647-2648 [Tralles]; no. 2991 [Sardis]. At Aphrodisias, there was a cult to Livia as Demeter, the Greek equivalent to Ceres (Grether 1946, 241, note 106).

40 Strickert 2011, 171, 251-255.

41 Tac. Ann. 5.1; Suet. Tib. 51.2; Dio 58.2.1; cf. Barrett 2002, 309-310. Tiberius had fallen out with his mother and issued no coins to mark her passing (Barrett 2002, 218). Tiberius refrained from visiting Livia during her final illness, nor did he attend her funeral. Tacitus implies that he was unwilling to relinquish the comforts of Capri to take the trouble to see off his mother. He curtailed the lavish tributes decreed to her memory by the Senate and denied her divine honours. Livia's apotheosis was delayed for 13 years, until Claudius accorded his revered grandmother this ultimate tribute.

$42 \quad R P C \mathrm{I}$, no. $4949=T J C$, no. 107 ; RPC I, no. S-4952A $=$ TJC, no. 110.

43 Strickert 2011, 239-240, 249-250.

44 Jos. BJ 2.184-187, 192-203; AJ 18.261-309; cf. Philo Leg. 188, 198-348.

$45 \quad R P C$ I, no. $4981=$ TJC, no. 120.

46 Besides Agrippa I's single coin issue in Jerusalem, there were significant emissions of coins in his name from the Caesarea Paneas and Caesarea Maritima mints. Appropriate for cosmopolitan Graeco-Roman cities with gentile majorities, there Agrippa was not restrained by scruples governing human images in Jewish Jerusalem. Rather, the coins from the two Caesareas were like those from other cities of their kind, which in- 
to refer to the deification of Julia Augusta (Livia) by her grandson Claudius on 17 January, $42 \mathrm{CE}^{47}$

There are hardly any other coins that demonstrably celebrate the award of divine honours to Livia. A complementary pair of dupondii struck in Rome, issued by Claudius in or after $41 \mathrm{CE}$, according to the nomenclature of the emperor presented on the obverse may fit the bill. The reverse of one depicts Ceres, veiled and draped, seated on a throne, holding two corn-ears and a long torch, with an inscription: CERES AVGVSTA. ${ }^{48}$ The reverse of the other bears the same image but refers to Livia more specifically, with the inscription DIVA AVGVSTA. ${ }^{49}$ Another rare candidate is a quadrans of the island of Cydonia dated to c. $41-43$ CE. ${ }^{50}$ The obverse bears the head together with the name of the Emperor Claudius, whereas the reverse displays the head of Livia, diademed, with the rather explicit inscription $\Theta E A \Sigma E B A \Sigma T A$ (literally, “divine empress”).

In addition to the Judaean coins commemorating Livia's death and apotheosis, there are the majority of coins issued under Valerius Gratus that carry the name of the consort of Augustus ${ }^{51}$ emphasising the high esteem in which she was held in that corner of the Roman Empire. The special regard for Livia in Judaea and especially by the Herodian monarchy attested by the coins finds ample confirmation in the literary sources. Josephus and Philo concur that the empress was a benefactor of the Temple in Jerusalem, making generous donations in support of the Temple rituals and presenting lavish gifts of gold vessels. ${ }^{52}$

Caesarea, the port city, established by Herod the Great, also benefited from Livia's largesse. To mark its inauguration (either in 12 or 10/9 BCE), a festival was staged in Augustus' honour, which was held every fifth year thereafter. It was modelled on the Isactian Games, with musical and athletic contests, along with beasts and gladiatorial shows, to which Augustus contributed; ${ }^{53}$ Livia sent some of her best treasures from Rome, and the total contribution from the emperor and his consort amounted to 500 talents. ${ }^{54}$

Livia's close friendship with the Herodians is also demonstrated by the fact that she was one of the beneficiaries named in Herod the Great's will. ${ }^{55}$ Further, on the death of Herod's sister, Salome, in c. 9-12 CE, Livia was bequeathed the major part of her estates,

clude portraits of the king, his consort and his son, and the personification of the Tyche of Caesarea. A few of the motifs were copied or adapted from contemporaneous Roman coin types; some others are highly original. For the coins of Agrippa I, see Burnett 2011-2014.

47 On the deification of Livia by Claudius, see Suet. Claud. 11.2; Dio 60.5.2; Seneca Apocol. 9.5; cf. Barrett 2002, 222-223. On the association of the three ears of grain on the coin of Agrippa I with that event, see Strickert 2011, 253-254.

48 RIC I I , Claudius, no. 94.

49 RIC I2, Claudius, no. 101.

50 RPC I, no. 1030.

51 Strickert 2011, 169-170.

52 Philo Leg. 291. Philo states that the gold vessels, along with other offerings, were a gift from Livia (Leg. 319), while Josephus affirms that both Livia and Augustus contributed precious utensils to the Sanctuary (BJ 5.562).

53 Jos. $A J$ 16.137-38. For the date of this event, see Smallwood 1981, 80, note 62. On Herod's games at Caesarea, see e.g. Patrich 2009, 185-188.

54 Jos. $A J 16.139$.

55 Jos. $A J$ 17.146, 190. 
namely Jamnia on the coast and Phasaelis and Archelais with their prestigious palm groves in the Jordan Valley. ${ }^{56}$

This deep affection and respect for Livia was maintained into the next generation of Herodian rulers. Two of Herod's sons and successors to portions of his kingdom, the tetrarchs Herod Antipas and Philip, renamed towns in Livia's honour. Antipas renamed Betharamphtha (Beth Ramatah in Hebrew) in Peraea, Julias (Josephus) or Livias (other sources) in her honour. ${ }^{57}$ Perhaps the town was given the name Livias at its foundation, but temporarily assumed the name Julias after Tiberius had Livia adopted into the Julian family on his accession; it later reverted back to its earlier name, as suggested by A. H. M. Jones. ${ }^{58}$ That would mean that Antipas' refoundation of Betharamphtha occurred prior to $14 \mathrm{CE}$.

We are informed by Josephus in the Antiquitates that Philip brought a large number of settlers to the village of Bethsaida on the north shore of Lake Tiberias and granted it the rank of a city "and named it after Julia, the daughter of (Augustus) Caesar." 59 The corresponding notice by Josephus in the Bellum compares and contrasts the cities founded by Philip and Herod Antipas: ${ }^{60}$

On his (Tiberius') accession, Herod (Antipas) and Philip continued to hold their tetrarchies and respectively founded cities: Philip built Caesarea (Philippi) near the sources of the Jordan, in the district of Paneas, and Julias in lower Gaulanitis; Herod built Tiberias in Galilee and a city which also took the name of Julia, in Peraea.

F. Strickert has shown that it is highly unlikely that Philip named his new city after the hapless natural daughter of Augustus; besides, there are no known cities anywhere in the Roman empire that were named in her honour. ${ }^{61}$ Strickert has also drawn attention to the fact that Roman sources dub Livia "the daughter of Divus Augustus," after her late husband's deification and concludes that Philip, like his half-brother Antipas, founded a city in honour of Livia. This explication gives literary coherence to the sentence in $B J 2.168$, with both tetrarchs honouring an emperor (in one case the husband of Livia and the other her son, Tiberius) and the empress Livia herself with new city foundations.

\section{The Second Period of Direct Roman Rule and Its Coins}

After the premature death of Agrippa I, Judaea reverted to direct Roman rule. Under the first two governors appointed by Claudius (41-54 CE), Cuspius Fadus and Tiberius Julius Alexander, "by abstaining from all interference with the customs of the country [they]

56 Jos. $B J$ 2.167; $A J$ 18.31; Pliny $H N 13.44$.

57 Jos. $B J$ 2.168; $A J$ 18.27. This town is called Julias consistently by Josephus ( $B J$ 2.252, 4.438; $A J$ 20.159), but later sources refer to it as Livias - Pliny $H N$ 13.44; Ptol. Geog. 5.16.9; Euseb. Onom. 12, 16, $44,48,168$.

58 Jones 1937, 275.

59 Jos. $A J 18.28$.

60 Jos. $B J 2.168$.

${ }^{61}$ Strickert 2011, 176-177. 
kept the nation at peace," so Josephus tells us. ${ }^{62}$ However, that was not entirely true, for Josephus reports in his Antiquities that Fadus raised tensions by attempting to regain Roman custody of the priestly vestments. ${ }^{63}$ His efforts, though, were frustrated by the intercession of Agrippa I's son with Claudius, who ordered him not to disturb the existing arrangement. Fadus also had to contend with growing disorder due to banditry and passions whipped up among the public by the false-prophet, Theudas, who was captured and executed. ${ }^{64}$ The two-year governorship of Tiberius Julius Alexander, nephew of Philo of Alexandria, who abandoned the Jewish faith, was less eventful, although the country suffered from a severe famine during his term, during which relief was provided by the royal house of Adiabene through the gifting of grain and dried fruit imports from Egypt and Cyprus. ${ }^{65}$ No coins were issued under either Cuspius Fadus or Tiberius Julius Alexander.

Matters took a turn for the worse under Ventidius Cumanus, with serious outbreaks of violence between Roman troops and elements of the Judaean population. ${ }^{66}$ Cumanus was insufficiently adept in dealing with these incidents, resulting in considerable bloodshed. His tardy response to an attack on Jewish pilgrims from Galilee by hostile Samaritans led to his recall, having been charged with receiving bribes from the Samaritans to turn a blind eye to the murder of the Jewish pilgrims. ${ }^{67}$ He was tried and sentenced to exile. ${ }^{68}$ This episode marks a change in the governance of the province, with Josephus declaring that "in Judaea matters were constantly going from bad to worse." ${ }^{\prime 69}$ Roman governors from this time are characterised more by their venality than the minding of their administrative responsibilities and care of their subjects. Their extraction of revenue from the population was now their main concern as aptly reflected in their title, procurator. Only two of them, Antonius (or Claudius?) Felix ${ }^{70}$ and Porcius Festus, saw fit to issue coins, two by the former and just one by the latter.

The overriding interests of Felix, the last appointee of Claudius, was to feather his own nest and throw his weight around. The harsh verdict on Felix by the Roman historian Tacitus was that he "practiced every kind of cruelty and lust, wielding the power of a king with all the instincts of a slave." ${ }^{\prime 11}$ His chief claim to fame were his three glittering marriages to royalty. Suetonius comments that he was the "husband of three queens."72 One of these wives was Drusilla, the youngest sister of Agrippa II, who abandoned her previous husband, Gaius Julius Azizus, the dynast of Emesa, for him in $54 \mathrm{CE} .{ }^{73} \mathrm{On}$ one of his two coins ${ }^{74}$ (Fig. 12), which were issued that same year, the 14th of Claudius'

62 Jos. $B J 2.221$.

63 Jos. AJ 20.6-14.

64 Banditry while Fadus was governor: Jos. AJ 20.2-5; Theudas: Jos. AJ 20.97-99; Acts 5.36.

65 Jos. AJ 20.51-53; Acts 11.29-30.

66 Jos. BJ 2.224-231; AJ 20.105-117.

67 Jos. $B J$ 2.232-242; $A J$ 20.118-130.

68 Jos. BJ 2.243-246; $A J$ 131-136.

69 Jos. AJ 20.160.

70 Tacitus (Hist. 5.9) gives the gentilicium of Felix as Antonius, but Josephus specifies it as Claudius.

This matter is discussed in Schürer 1973, 460-461, note 19; Kokkinos 1990.

71 Tac. Hist. 5.9.

72 Suet. Claud. 28.1.

73 Jos. AJ 20.143 .

$74 \quad R P C$ I, no. $4970=$ TJC, no. 342 . 
reign, is a pair of crossed palm branches, an emblem of Herod the Great, evidently intended to advertise his accomplishment in marrying into the Herodian royal house, as demonstrated by this author. ${ }^{75}$

The pair of coins issued during the tenure of Felix, in the final year of Claudius' reign $(54 \mathrm{CE})$, are distinctive for their Claudian dynastic concerns. The one featuring the crossed palm branches, a device that is exclusive to a Herodian context, ${ }^{76}$ is inscribed with the names of the emperor TI KAAY $\triangle$ IOC KAICAP ГEPM ("Tiberius Claudius Caesar Germanicus") on the obverse and that of his current wife Agrippina the Younger, IOY $\triangle$ IА АГРІППІNА ("Julia Agrippina”), contained in a laurel wreath on the reverse.

The complementary bronze echoes its companion, bearing a design of a crossed pair of oblong shields and two pairs of spears crossed on the obverse. ${ }^{77}$ This device is accompanied by the name of Nero Caesar, NEPW KAAY KAICAP ("Nero Claudius Caesar"), son of Agrippina by her previous marriage, and groomed as Claudius' successor after being formally adopted by the emperor on 25 February $50 \mathrm{CE}$; $^{78}$ see Fig. 13. The ensemble of shields and spears reproduces a motif on a Roman aureus and denarius, issued between 41 and $45 \mathrm{CE}$, celebrating the military successes of Claudius' father and younger son of Livia, Nero Claudius Drusus, in Germany from $14 \mathrm{BCE}$ until his early death in $9 \mathrm{BCE}$, as a result of a riding accident. ${ }^{79}$ This commemorative coin type was intended to confer lustre to Claudius and his lineage. The reverse of the Judaean coin depicts a date palm, emblematic of Judaea, and the name of Claudius' natural son by his previous wife Valeria Messallina, Britannicus Caesar, BRIT KAI(C). ${ }^{80}$ Britannicus was three years Nero's junior; in $54 \mathrm{CE}$, Britannicus would have been no more than 13 years of age, having being born on 12 February, $41 \mathrm{CE}^{81}$

If, after $50 \mathrm{CE}$, Nero had displaced Britannicus as Claudius' heir, how can the occurrence of both names on this coin be explained? Whilst Britannicus is never depicted on coins minted in Rome, he is occasionally shown together with Nero on provincial coins in one of three different configurations:

75 Jacobson 2014.

76 Jacobson 2014, 96-98.

77 RPC I, no. $4971=$ TJC, no. 340 .

78 Levick 2015, 81-84.

$79 R I C \mathrm{I}^{2}$, nos. 73 and 74 (Fig. 13a). The motif on the Roman coins is virtually identical, but includes in addition a pair of trumpets and vexillum. B. Kanael $(1963,55)$ has suggested that the vexillum was omitted on the Judaean coin in deference to Jewish feelings, probably having in mind the furore caused when Pontius Pilate permitted Roman soldiers to bring their military standards with them to Jerusalem.

${ }^{80}$ Britannicus was heir apparent at birth in $41 \mathrm{CE}$, but his mother's disgrace and execution in 48 BCE, followed by Claudius' marriage to Agrippina the younger and the displacement of Britannicus by the later consort's older son, as heir. The name Britannicus had been acquired through the award of the honorific title to Claudius by the senate in $43 \mathrm{CE}$, following his successful invasion of Britain. The emperor did not use that title for himself but bestowed it on his son instead (Dio 60.22.1-2). There are three undated coins struck at Caesarea Paneas prior to $50 \mathrm{CE}$, either by Agrippa II or one of the procurators of Judaea, perhaps Felix (RPC I, 670, 682; TJC, 178), which feature the adolescent Britannicus together with appropriate legends in Latin naming him (RPC I, nos. 4842-4844 = TJC, nos. 350-352).

81 Levick 2015, 63. 
1. Jugate heads of Britannicus and Nero Caesar. ${ }^{82}$

2. Britannicus and Nero Caesar shown on opposite sides of the same coin. ${ }^{83}$

3. Pairs of coins with Britannicus displayed on one and Nero Caesar on the other. ${ }^{84}$

From a close study of the literary sources, B. Levick was convinced that after $50 \mathrm{CE}$, Claudius wished for the joint succession of both boys. ${ }^{85}$ Early in $51 \mathrm{CE}$, while in his 14 th year, Nero received his toga virilis, a certification of Roman manhood, which made him eligible for appointment to high office, including the consulship and pontificate, which he achieved in March that year, thereby gaining him considerable advantage over Britannicus. But, in Claudius' eyes, his natural son remained in contention as successor. ${ }^{86}$ This would account for Britannicus occasionally being included with Nero on coins and for the two princes being mentioned together on the Judaean coin struck during the governorship of Felix. Nero's death in October 54 CE put paid to Britannicus' prospects and not long after the year-end, he too was no longer alive.

Porcius Festus arrived as the successor to Felix, to find brigandage rampant and he attempted to stamp out this disorder, but evidently without success. ${ }^{87}$ He was the last Roman governor to issue a coin, in the 5th year of Nero's reign, 58/59 CE (Fig. 14). The palm branch that is represented on the reverse can have a martial meaning, as mentioned above, being the symbol of victory in battle; it has been so interpreted on coins of the Hasmonaean kings and Herod the Great. ${ }^{88}$ This symbol therefore suited the moment in time when the clouds of war were gathering between Judaea and Rome.

\section{Conclusions}

The coinage of the Roman governors is broadly consistent with the picture presented in the literary sources of the changing conditions in Judaea from the deposition of Herod Archelaus in $6 \mathrm{CE}$ to 58/59 CE, the last year that "procuratorial" coins were issued, marked initially by a largely satisfactory modus vivendi and later by a deterioration of relations between the provincial administration and most of the Jewish population.

Coins issued in the early years of the Roman administration depict agricultural motifs reflecting the fecundity of the Land of Israel, which were compatible with Jewish sensibilities. One of the coin types struck under Valerius Gratus, on the theme of the fruits of the vine, was deemed sufficiently congenial to serve as a model for the design of the coins of the same denomination issued by the rebels during the first two years of the First Jewish Revolt.

Pontius Pilate broke with this convention by striking coins bearing Roman sacerdotal accoutrements, which may have been intended merely as symbols of imperial authority. One of his coin types was the first to refer to a Roman dynastic milestone, the death of

${ }^{82} R P C$ I, nos. 1182-1184 [Corinth]; no. 2132 [Sinope].

$83 R P C$ I, no. 2135 [Sinope]; no. 2371 [Pergamum].

${ }^{84} R P C$ I, nos. 2915-2916 [Laodicea]; nos. 2971-2972 [Hierapolis].

85 Levick 2015, 81-88.

86 Tac. Ann. 12.65; Suet. Claud. 43.1; Dio 60.34.1.

87 Jos. $B J 2.271 ; A J 20.185-188$.

88 Jacobson 2013b; 2014. 
the Empress Livia and is the only certain instance of a tribute to the passing of Augustus' consort on a contemporaneous coin. The two coins struck under Antonius Felix provide a fleeting glimpse of Roman dynastic politics at end of the Emperor Claudius' life. At the same time, Felix took the opportunity to boast his personal success in marrying into Herodian royalty. The earlier focus on Judaean agricultural themes had been displaced from the local coinage. It is possible that the display of Roman military prowess in the shape of the military insignia in commemoration of Claudius' father, Nero Claudius Drusus, may have been intended also as a show of Roman might at a time of spiralling insurgency in Judaea. ${ }^{89}$

There can be one or more explanations for the sporadic and irregular issuing of coins by the Roman governors (Hendin 2010,314). A dominant view is that coins were only produced whenever there was a shortage of small change in circulation and its corollary that when there was an ample volume of such coins in circulation the governors did not need to strike coins. A case in point has been mentioned by Kanael: "Agrippa I issued such a large number of coins of his standard series, [by which he means his Jerusalem prutah (RPC I 4981; TJC 120)] that for ten years afterwards no coins had to be struck by the procurators who succeeded him." ${ }^{90}$ Meshorer vaguely hints that there might another contributing factor, namely "not all of them [the governors] showed an interest in minting." 91 This could mean that some governors, especially the last two before the outbreak of the War, Lucceius (?) Albinus and Gessius Florus, showed little interest in the wellbeing of their Jewish subjects, and responding to their fiscal and other needs. ${ }^{92}$ Indeed, no coins were issued by either of these governors, for whom Josephus only has harsh words regarding their conduct.

89 Jos. BJ 2.253-70; $A J$ 160-178.

90 Kanael 1963, 55.

91 TJC, 168.

92 Jos. BJ 2.272-279. 

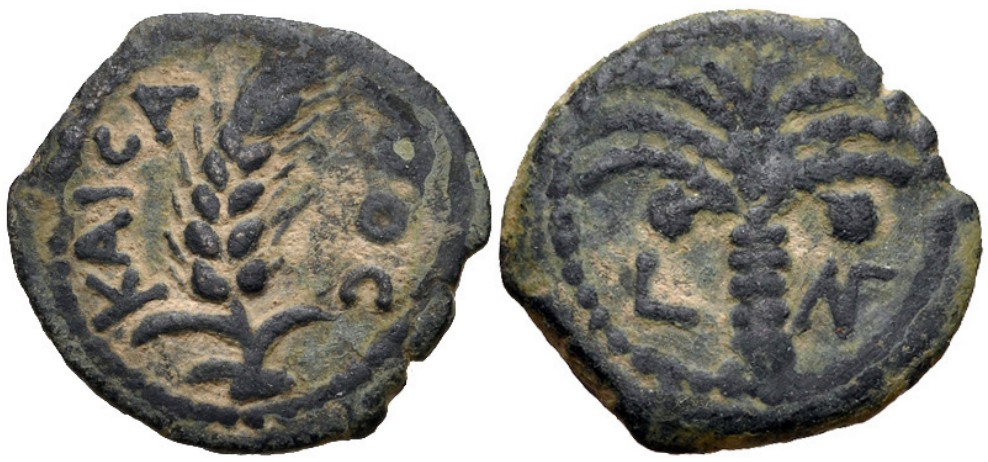

Fig. 1. Year 36 of the era of Augustus (beginning 31/30 BCE) $=5 / 6 \mathrm{CE} . R P C$ I, no. $4954=T J C$, no. 312. CNG Electronic Auction 273 (8 Feb. 2012), Lot 204 (Courtesy of Classical Numismatic Group, Inc.)
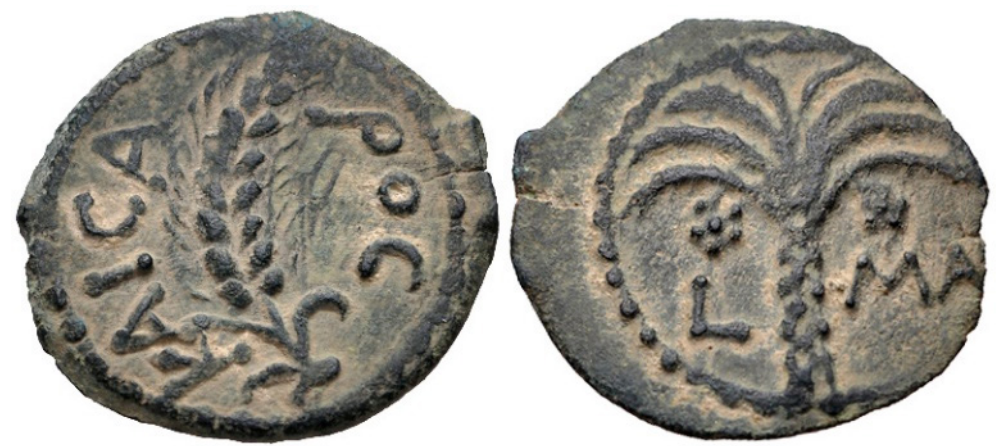

Fig. 2. Year 41 of the era of Augustus (beginning 31 BCE) $=10 / 11$ CE. RPC I, no. $4957=$ TJC, no. 315. CNG Electronic Auction 382 (7 Sept. 2016), Lot 275 (Courtesy of Classical Numismatic Group, Inc.)
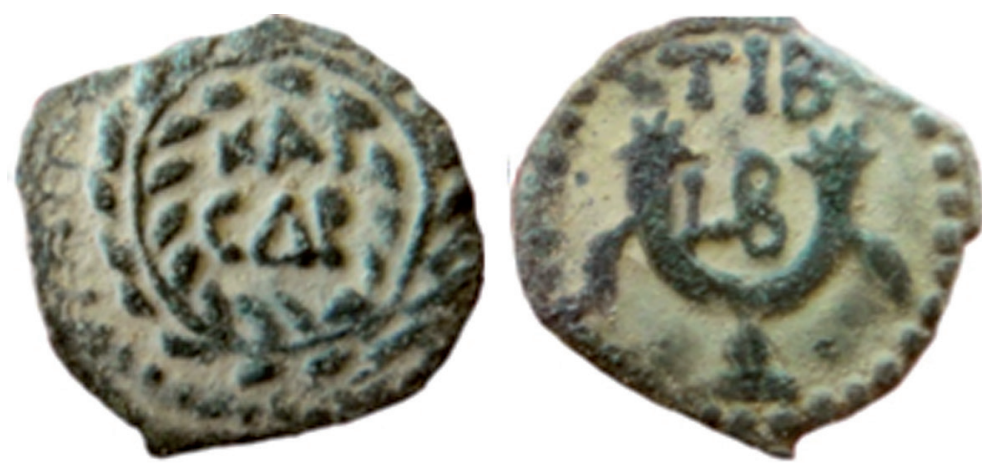

Fig. 3. RY 2 of Tiberius $=15 / 16$ CE. RPC I, no. $4958=$ TJC, no. 316. CNG Electronic Auction 251 (9 Mar. 2011), Lot 136 (Courtesy of Classical Numismatic Group, Inc.) 

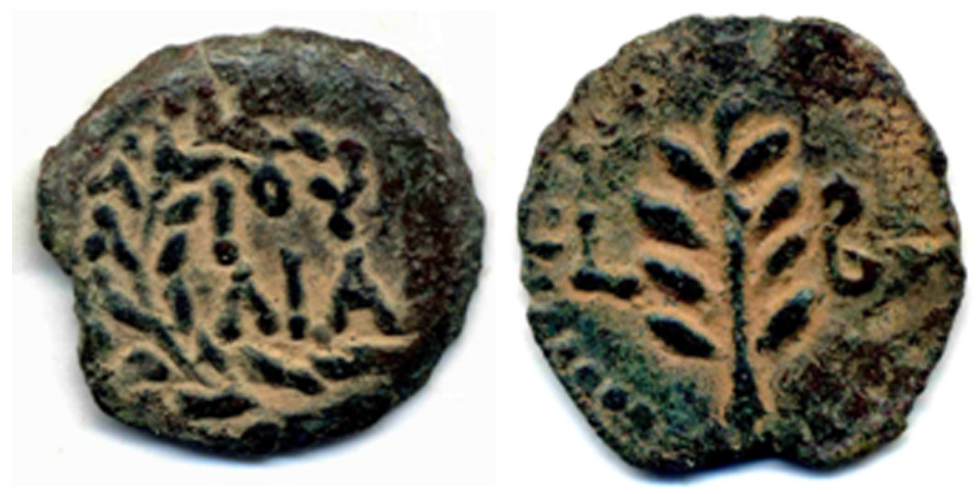

Fig. 4. RY 2 of Tiberius = 15/16 CE. RPC I, no. $4959=$ TJC, no. 317 (From a private collection, with permission)
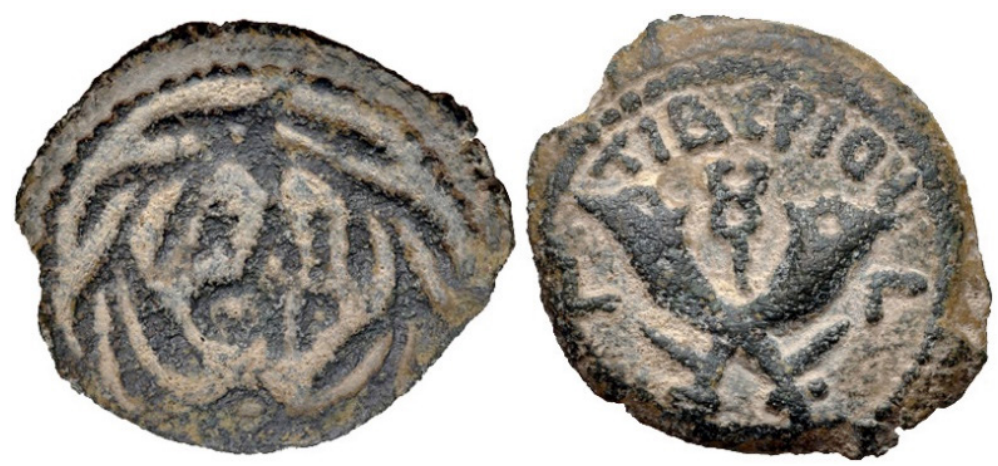

Fig. 5. RY 3 of Tiberius = 16/17 CE. RPC I, no. $4960=$ TJC, no. 320. CNG Electronic Auction 335 (24 Sept. 2014), Lot 371 (Courtesy of Classical Numismatic Group, Inc.)
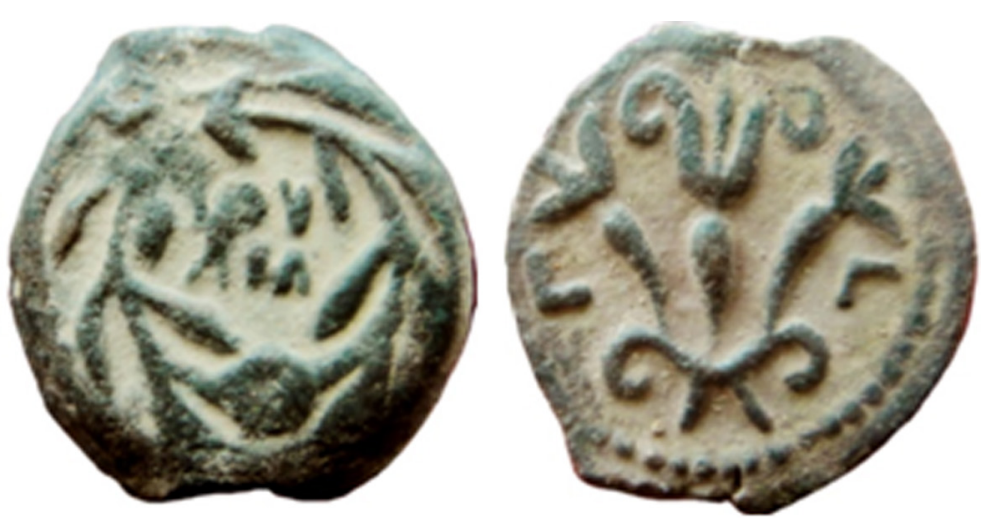

Fig. 6. RY 3 of Tiberius = 16/17 CE. RPC I, no. 4961 = TJC, no. 321 (Courtesy of Jean-Philippe Fontanille) 

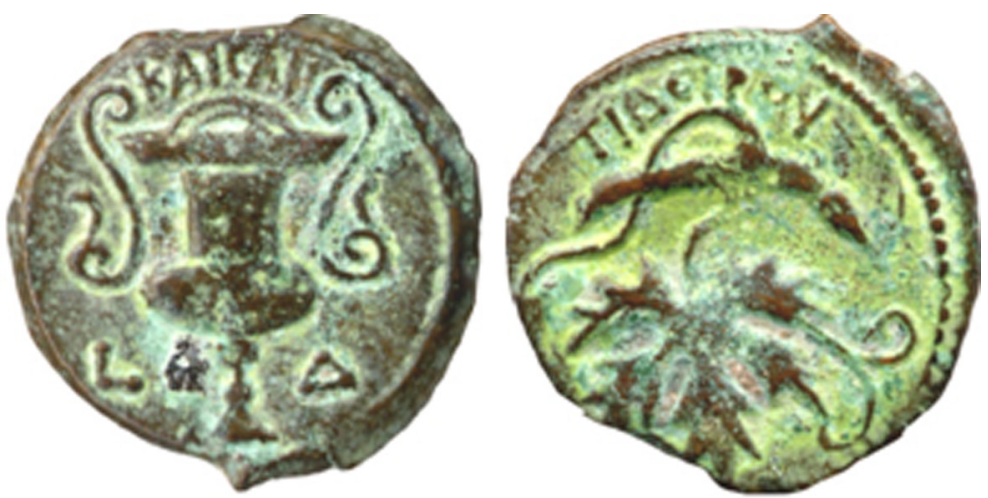

Fig. 7. RY 4 of Tiberius $=17 / 18$ CE. RPC I, no. $4962=$ TJC, no. 325 (Courtesy of Jean-Philippe Fontanille)
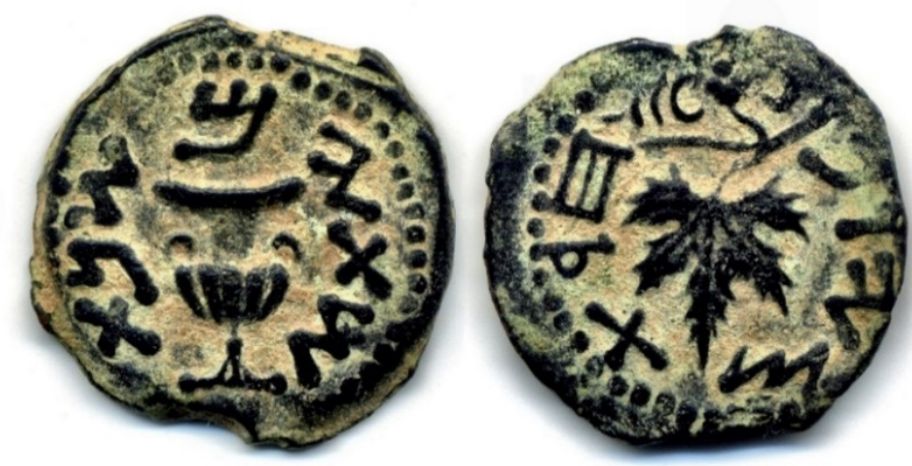

Fig. 7a. Year 2 of the Jewish War $=67 / 68$ CE. TJC, no.196 (Photograph of the author)
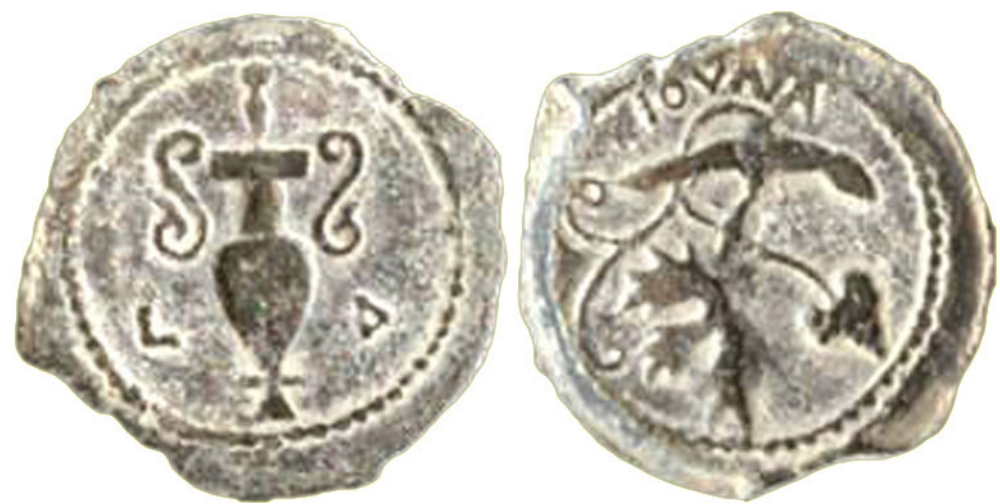

Fig. 8. RY 4 of Tiberius $=17 / 18$ CE. RPC I, no. $4963=$ TJC, no. 326 (Courtesy of Jean-Philippe Fontanille) 

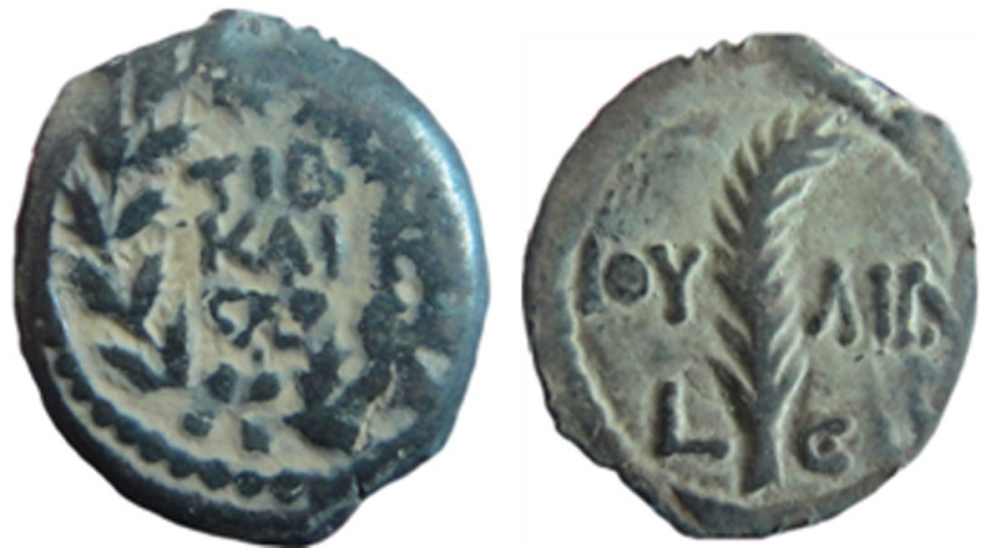

Fig. 9. RY 5 of Tiberius = 18/19 CE. RPC I; no. $4965=$ TJC, no. 328 (Courtesy of Jean-Philippe Fontanille)
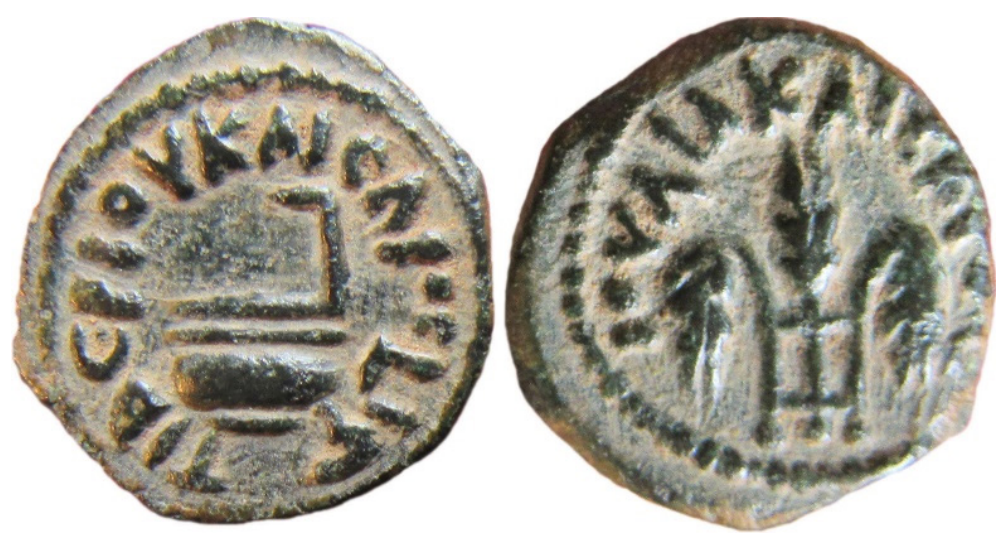

Fig. 10. RY 16 of Tiberius =29/30 CE. RPC I, no. $4967=$ TJC, no. 331 (Courtesy of Jean-Philippe Fontanille)
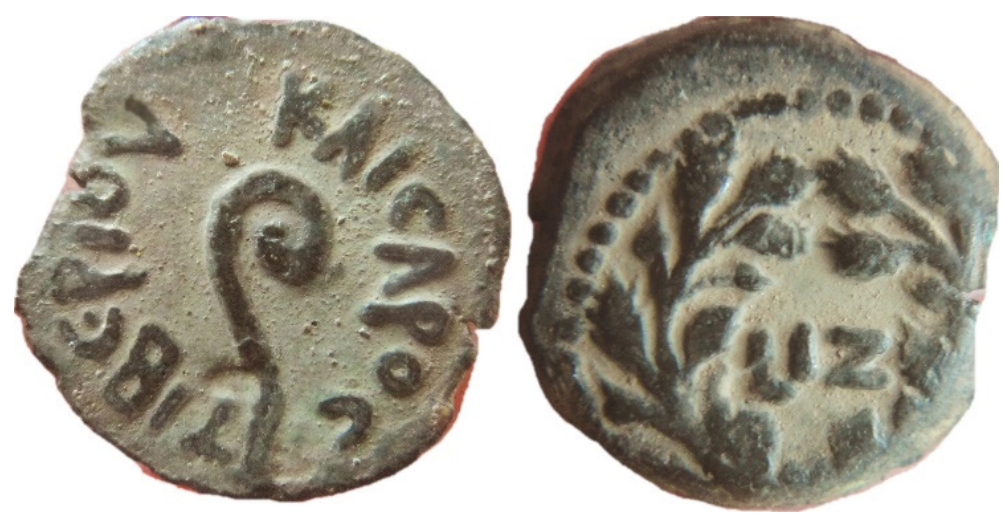

Fig. 11. RY 17 of Tiberius = 30/31 CE. RPC I, no. $4968=$ TJC, no. 333d (Courtesy of Jean-Philippe Fontanille) 

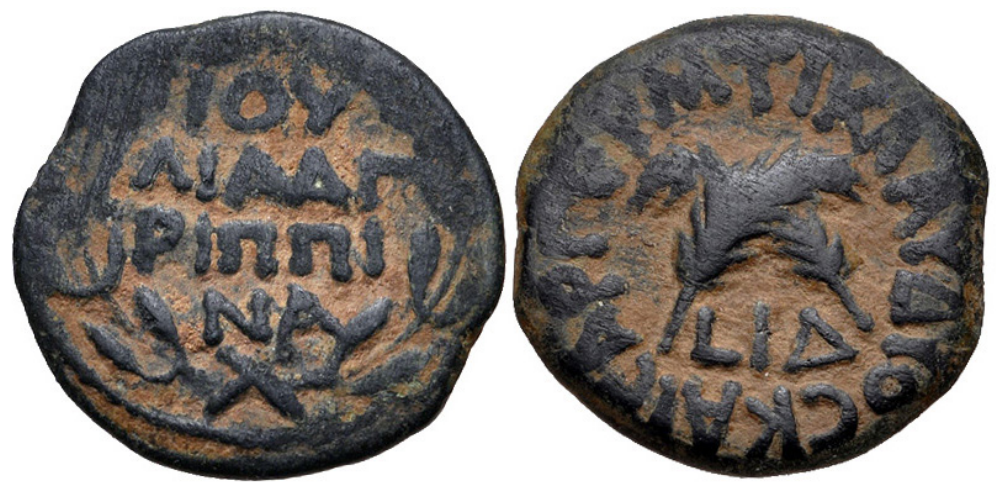

Fig. 12. RY 14 of Claudius $=54$ CE. RPC I, no. $4970=$ TJC, no. 342. CNG Electronic Auction 384 (12 Oct. 2016), Lot 464 (Courtesy of Classical Numismatic Group, Inc.)
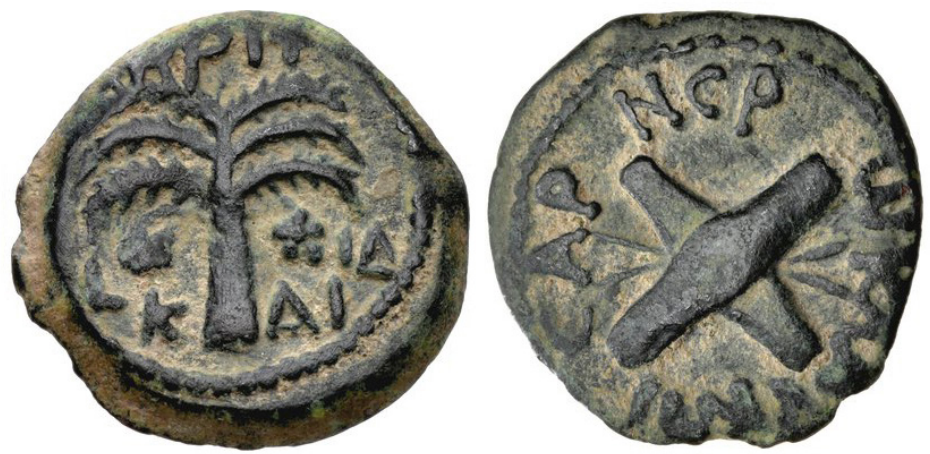

Fig. 13. RY 14 of Claudius $=54$ CE. RPC I, no. $4971=$ TJC, no. 340. CNG Mail Bid Auction 93 (22 May 2013), Lot 1019 (Courtesy of Classical Numismatic Group, Inc.)
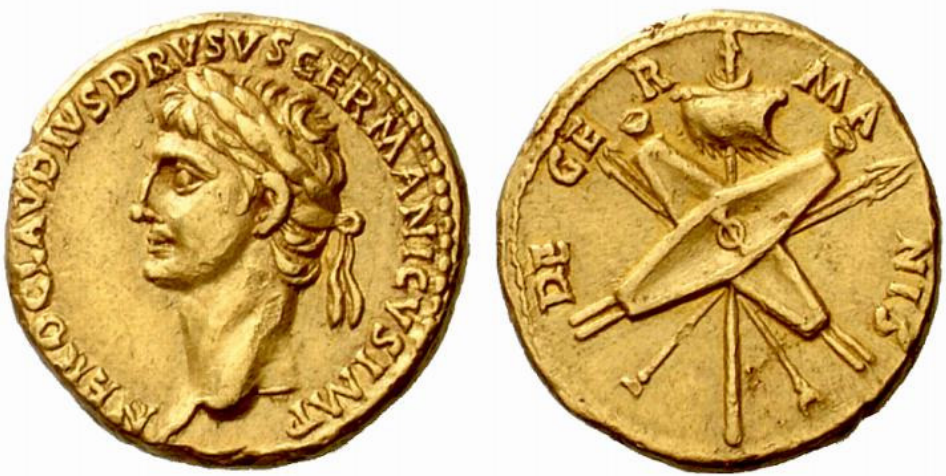

Fig. 13a. Undated, c. 41-45 CE. Aureus in the name of Nero Claudius Drusus, father of Claudius. RIC I2, Claudius no. 73. NAC Auction 45 (2 Apr. 2008), Lot 78 (Courtesy of Numismatica Ars Classica NAC AG) 

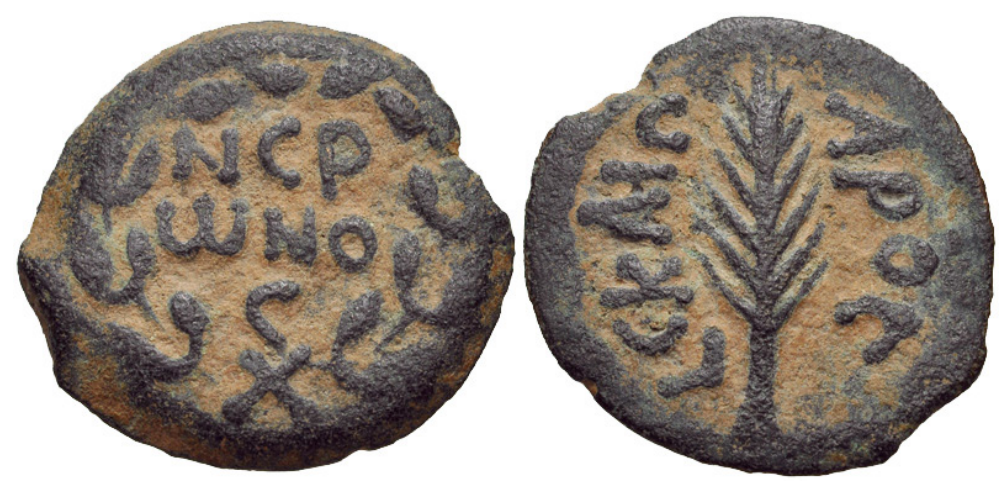

Fig. 14. RY 5 of Nero = 59 CE. RPC I, no. $4972=$ TJC, no. 345. CNG Electronic Auction 216 (12 Aug. 2009), Lot: 239 (Courtesy of Classical Numismatic Group, Inc.)

AbBreviations

AJC - Y. Meshorer, Ancient Jewish Coinage, 2 vols., Dix Hills, NY.

bNP online - H. Cancik, H. Schneider (eds.), Brill's New Pauly: Encyclopaedia of the Ancient World, 15 vols., English ed. C. F. Salazar, Leiden-Boston, 2002-2010.

RIC $\mathrm{I}^{2}-$ C. H. V. Sutherland, R. A. G. Carson (eds.), The Roman Imperial Coinage, vol. 1: From 31 BC to $A D$ 69, revised $2^{\text {nd }}$ ed., London 1984.

RPC I - A. Burnett, M. Amandry, P. Ripollès, Roman Provincial Coinage, vol. I (in 2 parts): From the Death of Caesar to the Death of Vitellius (44 BC-AD 69), London-Paris 1992.

$R R C-$ M. H. Crawford, Roman Republican Coinage, 2 vols., Cambridge 1974.

SC II - A. Houghton, C. Lorber, O. Hoover, Seleucid Coins: A Comprehensive Catalogue, Part II (in 2 vols.): Seleucus IV through Antiochus XIII, Lancaster, PA-London 2008.

TJC - Y. Meshorer, A Treasury of Jewish Coins from the Persian Period to Bar Kokhba, Nyack, NYJerusalem 2001.

\section{BIBLIOGRAPHY}

Amit, D., Gibson, S. (2014), Water to Jerusalem: The Route and Date of the Upper and Lower Level Aqueducts, in: C. Ohlig, T. Tsuk (eds.), Cura Aquarum in Israel II: Water in Antiquity: Proceedings of the $15^{\text {th }}$ International Conference on the History of Water Management and Hydraulic Engineering in the Mediterranean Region, Israel 14-20 October 2012, Siegburg: 9-41.

Ariel, D. T., (1982), A Survey of Coin Finds in Jerusalem (until the End of Byzantine Period), Liber Annuus 32: 273-326.

Ariel, D. T. (2011), A First Century CE Mint South of Jerusalem? Numismatic Evidence, in: D. Amit, G. D. Stiebel, O. Peleg-Barkat (eds.), New Studies in the Archaeology of Jerusalem and Its Region 5: $16^{*}-23^{*}$. 
Ariel, D. T. (2012), Judean Perspectives of Ancient Mints and Minting Technology, Israel Numismatic Research 7: 43-80.

Ariel, D. T. (2014), Review of David M. Jacobson and Nikos Kokkinos (eds.), Judaea and Rome in Coins, 65 BCE-135 CE, NC 174: 385-391.

Barrett, A. A. (2002), Livia: First Lady of Imperial Rome, New Haven, CT-London.

Bartman, E. (1999), Portraits of Livia: Imaging the Imperial Woman in Augustan Rome, Cambridge.

Boffo, L. (1994), Inscrizioni Greche e Latine per lo studio della Bibbia, Brescia.

Burnett, A. (2011/2014), The Coinage of Agrippa I, Israel Numismatic Journal 18: 69-106.

Elderkin, G. W. (1924), Kantharos: Studies in Dionysiac and Kindred Cult, Princeton.

Grether, G. (1946), Livia and the Roman Imperial Cult, AJPh 67: 222-252.

Györi, V. (2015), The lituus and Augustan Provincial Coinage, AAntHung 55: 45-60.

Hendin, D. (2003/2006), A New Coin Type of Herod Antipas, Israel Numismatic Journal 15: 56-61.

Hendin, D. (2010), Guide to Biblical Coins, $5^{\text {th }}$ ed., New York.

Jacobson, D. M. (2012), The Significance of the Caduceus between Facing Cornucopias in Herodian and Roman Coinage, in: D. M. Jacobson, N. Kokkinos (eds.), Judaea and Rome in Coins 65 BCE135 CE: Papers Presented at the International Conference Hosted by Spink, $13^{\text {th }}-14^{\text {th }}$ September 2010, London: $145-161$.

Jacobson, D. M. (2013a), Military Symbols on the Coins of John Hyrcanus I, Strata: Bulletin of the Anglo-Israel Archaeological Society 31: 43-56.

Jacobson, D. M. (2013b), The Lily and the Rose: A Review of Some Hasmonean Coin Types, NEA 76 (1): $16-27$.

Jacobson, D. M. (2014), Herod the Great's Royal Monogram, Israel Numismatic Research 9: 95-101.

Jacobson, D. M. (2015), Herod the Great, Augustus Caesar and Herod's 'Year 3' Coins, Strata: Bulletin of the Anglo-Israel Archaeological Society 33: 89-118.

Jones, A. H. M. (1937), The Cities of the Eastern Roman Provinces, Oxford.

Kanael, B. (1963), Ancient Jewish Coins and Their Historical Importance, Biblical Archaeologist 26 (2): 38-62.

Kokkinos, N. (1990), A Fresh Look at the gentilicium of Felix, Procurator of Judaea, Latomus 49: $126-141$.

Kokkinos, N. (2012), The Prefects of Judaea 6-48 CE and the Coins from the Misty Period 6-36 CE, in: D. M. Jacobson, N. Kokkinos (eds.), Judaea and Rome in Coins 65 BCE-135 CE: Papers Presented at the International Conference Hosted by Spink, 13 $3^{\text {th }}-14^{\text {th }}$ September 2010, London: 85-111.

Levick, B. (2015), Claudius, $2^{\text {nd }}$ ed., London.

Patrich, J. (2009), Herodian Entertainment Structures, in: D. M. Jacobson, N. Kokkinos (eds.), Herod and Augustus: Papers Presented at the IJS Conference, 21st-23rd June 2005, Leiden: 181-213.

Schürer, E. (1973), The History of the Jewish People in the Age of Jesus Christ (175 B.C.-135 A.D.), vol. 1, revised and edited by G. Vermes and F. Millar, Edinburgh.

Smallwood, E. M. (1981), The Jews under Roman Rule from Pompey to Diocletian: A Study in Political Relations, Leiden.

Spaeth, B. S. (1994), The Goddess Ceres in the Ara Pacis Augustae and the Carthage Relief, AJA 98: $65-100$.

Strickert, F. (2011), Philip’s City: From Bethsaida to Julias, Collegeville, MN.

Taylor, J. E. (2006), Pontius Pilate and the Imperial Cult in Roman Judaea, New Testament Studies 52: $555-582$.

Zlotnik, Y. (2012), Were Jewish Coins Struck on Attached Strips of Flans?, Israel Numismatic Research 7: 81-92 and pl. 7-10. 